\title{
Dynamic Modeling and Simulation of a PEM Fuel Cell (PEMFC) during an Automotive Vehicle's Driving Cycle
}

\author{
Mehmet Ali Biberci \\ Vocational School \\ Cankiri Karatekin University \\ Cankiri, Turkey \\ m.alibiberci@karatekin.edu.tr
}

\author{
Mustafa Bahattin Celik \\ Faculty of Engineering \\ Karabuk University \\ Karabuk, Turkey \\ mcelik@karabuk.edu.tr
}

\begin{abstract}
Polymer Electrolyte Membrane Fuel Cells (PEMFCs) are the most appropriate type of fuel cells for application in vehicles due to their low operational temperature and high-power density. In this paper, a zero-dimensional, steady state thermodynamic modeling for an automotive $90 \mathrm{~kW}$ PEMFC system has been built up in order to investigate the effects of operating parameters such as vehicle acceleration and operating pressure on the size of the system elements, heat and water system constitution, fuel consumption, and efficiency. A dynamic model was formed for the fuel cell power system in MATLAB. Power output and power losses of the system were investigated at 3atm operation pressures.
\end{abstract}

Keywords-dynamic modeling; fuel cell system; PEM; thermal analysis;MATLAB

\section{INTRODUCTION}

PEM (Proton Exchange Membrane or Polymer Electrolyte Membrane) fuel cells are considered candidates for automotive applications due to their low operational temperature and highpower density. Even so, fuel cell systems face substantial barriers to commercialization due to their high price and short lifespan. PEMFC durability is mainly compromised by the degradation of the membrane electrode assembly during longterm operation [1]. Generally, the fuel of a PEMFC is pure hydrogen. The basic electrochemical reaction cell consists of one anode and one cathode electrode where on their surface electrochemical reactions occur and conduct ions from the one to the other, and the external circuit between electrodes for current flow [2-4]. Many research attempts for automotive applications focus on PEMFCs due to their capacity of higher power density and faster start-up compared to other fuel cell types. Water and heat management for PEMFCs is one of the key technical issues that must be resolved in order to be used in automotive applications. Proper water and thermal management is significant for optimizing the carrying out of a fuel cell stack. Water and heat management in automotive fuel cell systems can be classified and analyzed at cell and system levels. The cell level fields investigate the effects of parameters such as pressure, rate of flow, temperature, humidity, and membrane heaviness on the performance of the fuel cell stack
[5-9]. Authors in [10] studied the PEM fuel cell engine system which is used in transportation applications. This system consists of a compressor, humidifiers, pressure regulator, hydrogen storage tank, cooling system, heat exchanger and the fuel cell stack. The system performance was looked into by parametric studies of energy, exergy and work output values by changing operating conditions and system parameters. The results demonstrated that the system efficiency increases with the increase of temperature and pressure and that an increase in relative humidity of the system has a positive effect on the efficiency and power product values. In addition, the results showed that the efficiency increases with the decrease of membrane thickness, anode stoichiometry, and cathode stoichiometry. The model was developed in [11] in order to study the water and thermal management and balance of the fuel cell stack. The results showed that the decrease of air humidity increases the ionic resistance eventually and it causes a significant drop in the voltage. In addition, the air stoichiometric ratio must be greater than one to remove the produced water from the stack in order to prevent the cathode from flooding. Furthermore, the operating temperature of the cell significantly affects the fuel cell performance. Higher temperature increases the need for humification and water production cannot meet the corresponding demand.

This work presents a general zero-dimensional PEM fuel cell model for a vehicle application. The model was developed in order to study water and thermal management and the balance of the fuel cell stack of an automotive PEM fuel cell system with a maximum power of $90 \mathrm{~kW}$. A model of the fuel cell power system was created to power a true automotive vehicle (weight $=1880 \mathrm{~kg}$, air friction coefficient $=0.65$, front surface area $=2.68$, rolling resistance coefficient $=0.012$ ). Dynamic modeling was carried out with all its components (auxiliary units, fuel cell, and aerodynamic structure of the vehicle). The analysis of the system was run on the MATLAB program and during the ECE-15 driving cycle, the power required for the vehicle, the fuel cell current value, the fuel cell water and heat management, the required power amounts for auxiliary equipment, and the amount of hydrogen consumed etc. values were studied. 


\section{SYSTEM DESCRIPTION}

\section{A. Overall PEMFC System Model}

In this chapter, a common zero-dimensional PEMFC example is presented for automotive applications. The first step in the evolution of such a model is the innovation of the system layout including the fuel cell stack and auxiliary equipment. As explained below, as the operational pressure is increased the layout from the system changes due to the cooling system requirements of the compressed air. In this paper, system simulations were carried out at operating pressure of $3 \mathrm{~atm}$. Figure 1 demonstrates the formal diagram of an automotive PEMFC system proposed for 3atm operating pressure. This diagram is similar to the existing commercial PEMFC automotive systems accessible in the market and consists of components necessary to add reactants, remove the generated heat, and manage the produced water. The fuel cell stack demands three flow systems that interact with each other: air supply system, hydrogen supply system, and water and thermal management systems.

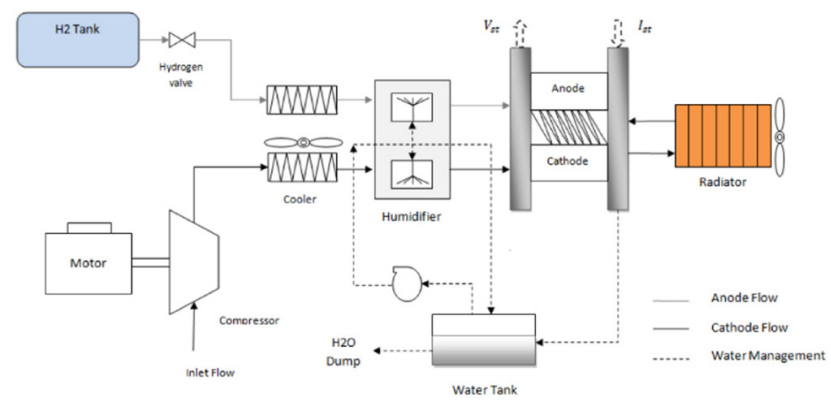

Fig. 1. Schematic view of a fuel cell power system

The air provision system consists of a compressor, an air cooler (intercooler), a humidifier, and a heater. Air supply at high pressure is provided by the compressor. The compression process causes a temperature rise in the supplied air. To lower the temperature of the entering air to the humidifier, the air transits from an intercooler. The air is moisturized by the humidifier before ingoing to the cathode side of the fuel cell stack to ensure a suitable hydration level of the membrane. The unused air leaving the stack can be heated by the heater and used to increase the hydrogen temperature through a heat exchanger in the hydrogen supply line. The hydrogen supply system consists of a hydrogen tank, a pressure regulator valve, a heat exchanger, a humidifier, and the unused hydrogen recycle line. The hydrogen is stored in a tank at high pressure. The pressure regulator valve is used to adjust the flow rate of the hydrogen. The heat exchanger helps warming the incoming hydrogen which is then fed to the humidifier. Like air flow, hydrogen is moisturized by the humidifier prior to entering the anode side of the fuel cell stack. The recycling hydrogen system is used to accumulate the hydrogen that has not reacted in the stack and sends it back to mix with the entering anode flow after the humidifier. The water system and thermal management system consist of a radiator, a fan, pumps, and a water storage tank. The chief function of the radiator is to maintain the fuel cell stack at its operation temperature by dissipating heat to the coolant. The fan increases the potency of heat convection at lower vehicle speeds. The pumps recirculate the water and the coolant through the system and the water storage tank is used to reconstruct and save the generated water. The generated water is used to moisturize the reactant gases through the humidifier [2,12].

\section{B. Vehicle Force and Torque Parameters}

In general, the force and torque parameters of the EV (Electrical Vehicle) powertrain are borrowed from the wellestablished definitions used in ICEV (Internal Combustion Engine Vehicle) for powertrain. Figure 2 shows the force components that the vehicle powertrain must provide for the vehicle to travel, which include the road load $F_{\text {load }}$ and the acceleration force $F_{\text {accel }}$. This road load consists of three main components as described by (1): the aerodynamic drag force $F_{\text {drag, }}$ the rolling resistance force $F_{\text {resist }}$, and the climbing force $F_{\text {climb }}[11]$.

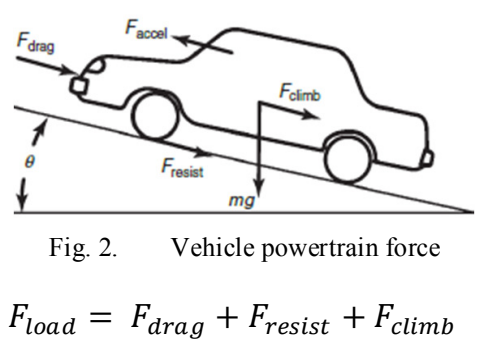

\section{Driving Cycle}

In the European Union, a vehicle is commonly tested using two kinds of driving cycles. The first one is the urban driving cycle known as the ECE-15 which was introduced in 1999. It was devised to represent city driving conditions in Paris or Rome. As shown in Figure 3, it simulates an urban trip of $4052 \mathrm{~m}$ at an average speed of $18.7 \mathrm{~km} / \mathrm{h}$ and maximum speed of $50 \mathrm{~km} / \mathrm{h}$. It is particularly useful for testing the urban driving performance of an EV [13].

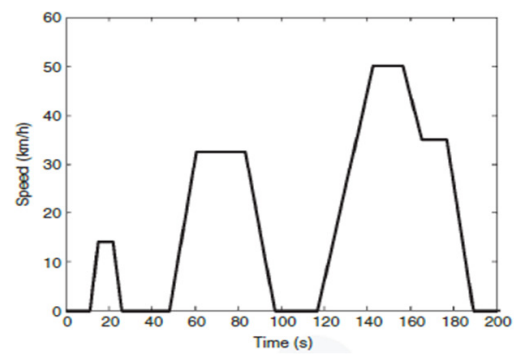

Fig. 3. ECE-15 driving cycle

\section{Simulation Software}

A zero-dimensional and steady state PEMFC model is developed and presented. This example was enforced in MATLAB which contains several types of heat exchangers, compressors, pumps, mixtures, separators, etc. that have been developed over the years. The users can add new elements to the library components, which is the case for the auxiliary equipment in this study. The equations used for modeling were either analytical or semi-empirical as 
described below. The accuracy of the theoretical results was validated by stack data and the ECE-15 driving cycle produced by this model matches very well the corresponding stack data. The presented model can be used for all types of PEMFC stacks by replacing the adjusting parameters explained in detail below $[2,14]$.

\section{PEM MODEL AND BASIC EQUATIONS}

To establish a general, zero-dimensional model of PEMFC, a semi-empirical solution was applied for reproducing the experimental polarization curve of the fuel cell. The average cell voltage can be analytically expressed by the following expression:

$$
V_{\text {cell }}=E-\eta_{\text {act }}-\eta_{\text {ohmic }}-\eta_{\text {conc }}
$$

where $E$ is the open circuit voltage. $\eta_{a c t}, \eta_{\text {ohmic }}, \eta_{\text {conc }}$ are activation, ohmic, and concentration losses respectively. There are numerous equations proposed in the literature for predicting the aforementioned terms which are elaborated below [14]:

$$
V_{\text {stack }}=v_{\text {cell }} \cdot n_{\text {cell }}
$$

where the stack voltage $V_{\text {stack }}$ is simply the cell voltage multiplied by the $n_{\text {cell }}$ number of cells [15],

$$
P_{e}=i . v_{\text {cell }} . n_{\text {cell }}=i . V_{\text {stack }}
$$

where $P_{e}$ is the power output of the fuel cell stack (W) [15].

\section{A. Activation Loss}

The activation losses in fuel cell voltage can be calculated using the well-known Butler- Volmer equation [16]:

$$
V_{\text {act }}=\frac{R T}{n \alpha_{\text {anode } F}}\left[\ln \frac{i}{i o}\right]_{\text {anode }}+\frac{R T}{n \alpha_{\text {cathode }} F}\left[\ln \frac{i}{i o}\right]_{\text {cathode }}
$$

where $i$ is the current density, io is the reaction exchange current density, $n$ is the number of exchange protons per mole of reactant, $F$ is Faraday's constant, and $\alpha$ is the charge transfer coefficient [17].

\section{B. Ohmic Loss}

The total fuel cell ohmic losses can be written as [16]:

$$
\begin{gathered}
E_{\text {ohmic }}=i A \Sigma R \\
=i A\left[\left(\frac{L}{\sigma A}\right)_{\text {electroyle }}+\left(\frac{L}{\sigma A}\right)_{\text {cathode }}+\left(\frac{L}{\sigma A}\right)_{\text {anode }}\right]
\end{gathered}
$$

where $L$ is the thickness of the electrolyte layer, and $\sigma$ is the conductivity, and $A$ is the active area of the fuel cell.

\section{Concentration Loss}

The concentration losses can be calculated using (7) [17]:

$$
V_{\text {conc }}=\frac{R T}{n F} \ln \frac{i_{L}}{i_{L}-1}
$$

where $i_{L}$ the limiting current density, which is the point where the current density becomes large and the reactant concentration falls to zero, so the fuel cell will not be able to produce a higher current density than its limiting current density.

\section{Fuel Cell Thermal Efficiency}

Generally, the thermodynamic fuel cell efficiency is the relation between the electrical power produced and the total rate of fuel energy entering the fuel cell:

$$
\eta_{\text {ther }}=\frac{I . V_{\text {cell. }} n_{\text {cell }}}{\dot{m}_{\mathrm{H}_{2}, \mathrm{in} \cdot \mathrm{HHV} \mathrm{H}_{2}}}
$$

\section{E. Hydration Management of the Membrane}

The water content in the polymer electrolyte plays a significant role in PEMFC stack lifetime and the ionic resistance of the membrane. Low humidification in the membrane causes a rapid increase of the ionic resistance and high humidification will cause too much liquid water to overflow into the reactant channels and fill the pores in the electrodes. In order to have high ionic conductivity in the membrane, it should be fully hydrated. Hydration can be achieved by the humidification of gases, or by designing the fuel cell to allow the product water to hydrate the membrane $[14,18]$. In this study both methods are applied. Generally, diffusion of water in the polymer electrolyte is expressed in two terms: one is the electro osmotic drag phenomenon, which is representative of the number of water molecules associated with protons $\left(\mathrm{H}^{+}\right)$while crossing the membrane. But when the water is generated in the cathode side this phenomenon is the other way round. Water concentration gradient makes the water move from the cathode to the anode side, a phenomenon called water back diffusion [14]. Water molar flux due to electroosmotic drag can be defined as:

$$
m_{\text {drag }}=M W_{H_{2 O}} \cdot n_{d} \cdot \frac{i \cdot A_{\text {cell }} \cdot n_{\text {cell }}}{F}
$$

where $n_{d}$ is the electro-osmotic drag coefficient in water molecules per proton. The electro-osmotic drag coefficient $n_{d}$ can be calculated from the membrane water content $\lambda_{m}$ [2]:

$$
n_{d}=0.0029 \lambda_{m}^{2}+0.05 \lambda_{m}-3.4 .10^{-19}
$$

The water content in the membrane, $\lambda_{m}$ is defined as the ratio of water molecules to the number of sulfonic acid groups within the ionomer and is calculated from the water activity $a_{W}$ [2]:

$$
\lambda_{m}=0.043+17.8 a_{W}-39.85 a_{W}^{2}+36 . a_{W}^{3}
$$

Water activity is defined as:

$$
a_{W}=\frac{y_{V} P}{P_{s a t}(T)}=R H
$$

where $P$ is the pressure of the anode or the cathode. The amount of water concentration across the membrane that is caused by back diffusion is assumed equal to 0.9 of water transfer by electro osmotic drag.

\section{F. Mass Balance}

Mass balance equations are applied for each composition in the reactants separately. Water mass balance can be written as:

$$
\begin{gathered}
\dot{m}_{\mathrm{H}_{2} \mathrm{O}_{\mathrm{Aur}, \text { ln }}}+\dot{m}_{\mathrm{H}_{2} \mathrm{O}_{\text {gen }}}-\left(\dot{m}_{\text {drag }} \cdot A_{\text {cell }} \cdot M_{\mathrm{H}_{2} \mathrm{O}} \cdot 10^{-3}\right) \\
=\dot{m}_{\mathrm{H}_{2} \mathrm{O}_{\text {Air }} \text { out }}(13) \\
\dot{m}_{\mathrm{H}_{2} \mathrm{O}_{\text {fuel }, \text { ln }}}+\dot{m}_{\mathrm{H}_{2} \mathrm{O}_{\text {gen }}}-\left(\dot{m}_{\text {drag }} \cdot A_{\text {cell }} \cdot M_{\mathrm{H}_{2} \mathrm{O}} \cdot 10^{-3}\right)
\end{gathered}
$$




$$
=\dot{m}_{H_{2} O_{\text {fuel }}, \text { out }}
$$

These equations represent the water mass balance on the cathode and anode sides respectively which can be liquid or vapor. $A_{\text {cell }}$ is the active cell area and $M_{\mathrm{H}_{2} \mathrm{O}}$ represents the water molecular weight. $\dot{m}_{\mathrm{H}_{2} \mathrm{O}}$ is the water mass flow rate and subscripts in, out and gen represent inlet, outlet and generated respectively [14].

\section{G. Heat Transfer Balance}

The energy released in the electrochemical reaction must be taken away from the stack in order to maintain the desired constant temperature. The thermodynamic steady state energy balance of the fuel cell is given as:

$$
\sum Q_{i, \text { in }}=\sum Q_{i, \text { out }}+W_{e l}+Q_{\text {cool }}+Q_{\text {env }}
$$

where $Q_{i, i n}$ is the rate of energy entering with the reactant gases, $Q_{i, \text { out }}$ is the rate of energy leaving with the unused reactant gases, $W_{e l}$ is the electrical power generated, $Q_{c o o l}$ is the rate of heat carried from the fuel cell to the coolant, and $Q_{e n v}$ the rate of heat dissipated by the exposed stack surface to the environment.

\section{H. Total System Power and System Thermal Efficiency}

The efficiency of the fuel cell power system is the relation between the net electric power output and the total rate of fuel energy entering the fuel cell:

$$
\eta_{\text {sys }}=\frac{P_{\text {in }}}{P_{\text {out }}}
$$

where the output electrical energy $P_{\text {out }}$ is:

$$
\begin{gathered}
P_{\text {out }}=P_{e}-P_{\text {aux }} \\
P_{\text {in }}=m_{H_{2}, \text { in }} . H H V_{H_{2}}
\end{gathered}
$$

where the gross output power $P_{e}$ was calculated (4) and the parasitic loads by all the auxiliary system equipment $P_{\text {aux }}$ is the sum of all parasitic loads, commonly:

$$
P_{\text {aux }}=P_{\text {comp }}+P_{\text {pump }}+P_{\text {fan }}+P_{\text {heater }}
$$

where $P_{\text {comp }}$ is the power of the compressor, $P_{\text {pump }}$ is the power of hydrogen recirculation and cooling circuit pumps, $P_{\text {fan }}$ is the power of cooling circuit fan, and $P_{\text {heater }}$ is the electrical power of the heater.

\section{RESULTS AND DISCUSSION}

The simulation model was implemented using the above formulation systems within the ECE-15 driving cycle. In this section, an automotive PEMFC system is simulated in MATLAB. The described aboce thermodynamic models for compressors, pumps, humidifiers, and heat exchangers are required to operate the PEMFC system under the required conditions. Figure 4 shows the required power output as a function of vehicle speed for $3 \mathrm{~atm}$ working pressure. As can be seen, the change in speed values directly affects the required output power. Figure 5 shows the dissipation of auxiliary power as a function of vehicle speed at 3atm operating pressure. The auxiliary components include a compressor, an electric heater, a coolant pump, an injection pump, a radiator fan, and an intercooler fan. In this way, it is possible to see that the electrical power consummation by the fan grows faster than the electrical power consumed by the other auxiliary components. It is further noted that the compressed air will need to be cooled before it enters the humidifier using the intercooler. It is stated that the temperature of the air coming to the humidifier drops in an air cooler.

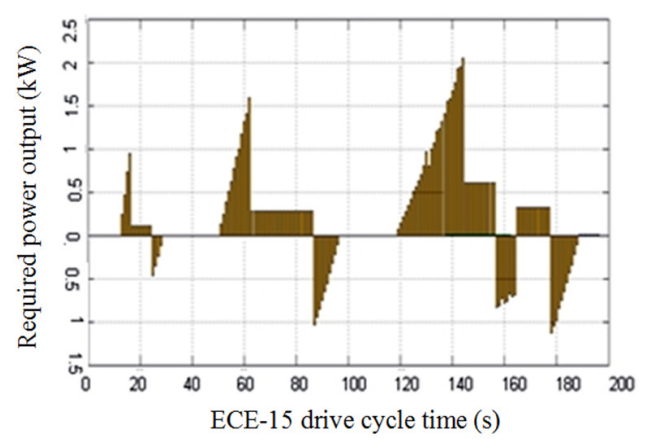

Fig. 4. Power output as a function of vehicle speed

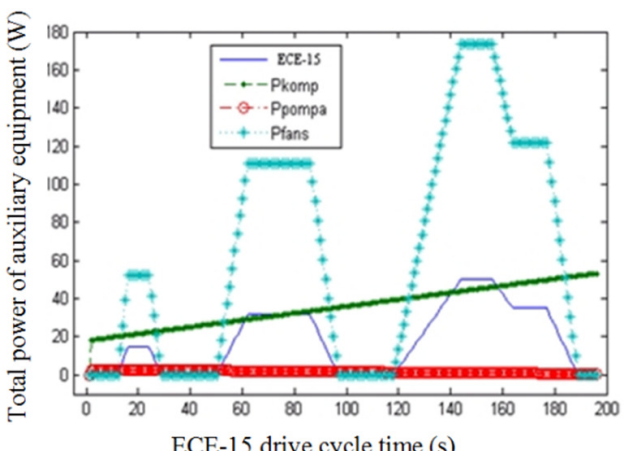

Fig. 5. Auxiliary equipment power requirement as a function of vehicle speed

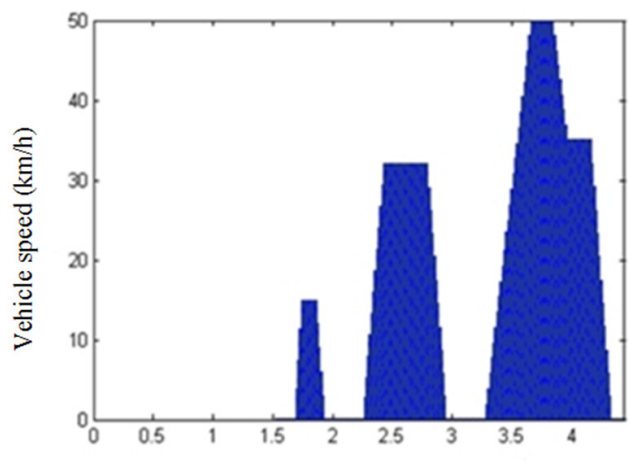

Fig. 6. Vehicle speed vs cumulative hydrogen fuel consumption

The electrical energy generated by a fuel cell is directly proportional to the amount of fuel consumed, because each mole of fuel provides specific electron moles. Figure 6 shows the consumption of hydrogen as a function of vehicle speed. When the vehicle speed increases, more energy is needed, so more fuel is consumed. Figure 7 shows the efficiency value as a function of vehicle speed indicating fuel cell thermal 
efficiency and system thermal efficiency. The fuel cell thermal efficiency curves present the relationship between the generated electricity and the maximum usable operation for the vehicle drive. The curves of the fuel cell thermal efficiency are decreased when thespeed of the vehicle increases due to the increase in the fuel consumption of the vehicle. It is also seen that an increase in working pressure increases the fuel thermal efficiency due to an increase in power output at high pressure from the fuel cell. In the system thermal efficiency curves, it can be seen that the increase in vehicle speed from $0 \mathrm{~km} / \mathrm{h}$ to $50 \mathrm{~km} / \mathrm{h}$ reduces significantly the system's thermal efficiency. This is mainly due to the electrical energy consumed by the compressor and other auxiliary components. By entering the appropriate operating parameters, the model produced in this study can perform system optimization and select the best operating condition for the system.

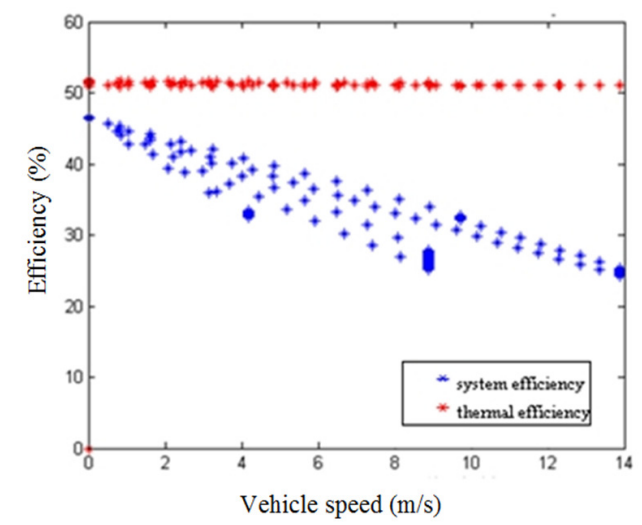

Fig. 7. System and thermal efficiency throughout the driving cycle

Figure 8 shows the water balance of the PEMFC system, the amount of water entering the system in the ambient air, and the amount of water injected into the humidified gases.

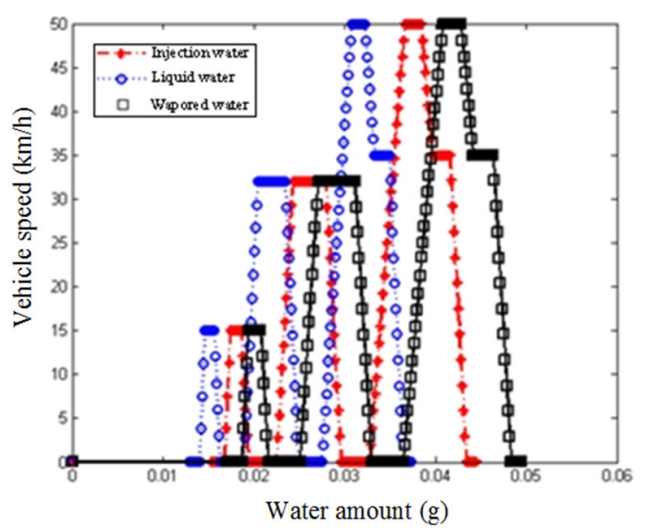

Fig. 8. Water management values during ECE-15 driving cycle

The water produced in the cathode due to the electrochemical reaction must be greater than or equal to the amount of water exiting the system. The water in the exhaust may be liquid or gaseous. The condition of the water depends on the operating conditions of the fuel cell (air stoichiometric ratio and operating pressure and temperature). Liquid water is easily separated from the gas flow in the condenser. Figure 8 shows the amount of water (liquid and vapor) at the outlet of the stack required for humidification as a function of vehicle speed for $3 \mathrm{~atm}$ pressure. As a result it is concluded that the average value of water at the exit of the fuel cell stack consists of $60 \%$ liquid water and $40 \%$ water vapors. At high pressures, the vapor pressure of the water is high, so the boiling point of the water increases. Therefore, the amount of liquid water increases with increasing working pressure. It also appears that the liquid water at the exit of the fuel cell is larger than the injected water and is sufficient to moisten the reagents before entering the fuel cell without using a condenser. Thermal management is one of the most important features in the development of the fuel cell stack system because heat is produced in large quantities by an electrochemical reaction in a PEM fuel cell. If the rate of generated heat is too high, the fuel cell overheats and may cause membrane dehydration. Low temperatures reduce the speed of the chemical reaction, reduce efficiency, and can cause water condensation and electrodes to overflow. As noted above, proper thermal management is required to maintain the required performance and durability temperatures of the cells and to prevent the stack from heating up the fuel cell stack system. The heat balance of the fuel cell stack as a function of vehicle speed is shown in Figure 9. The sum of the generated electrical energy, the rate of energy released by unused reactive gases and the rate of heat removal from the fuel cell should be equal to the rate of energy entering with the reactant gases.

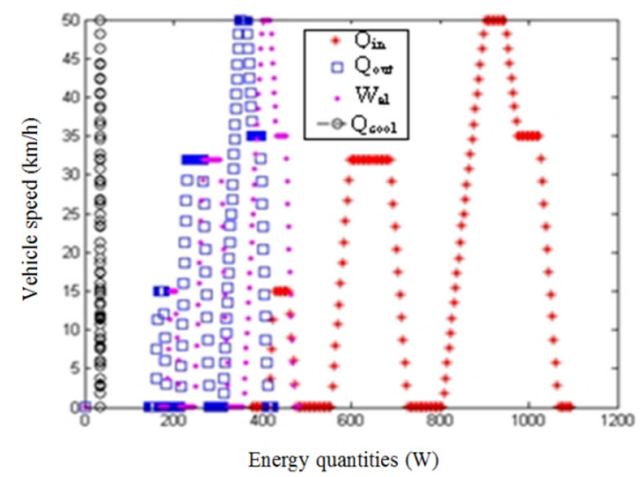

Fig. 9. Energy quantities during the ECE-15 driving cycle

The size of the heat exchanger (radiator) depends on the amount of heat to be extracted from the fuel cell stack and is influenced by the operating pressure. Figure 10 shows that as the speed of the required heat exchanger area increases the power from the fuel cell stack increases and the effective area of the radiator is also increased in order to spread the waste heat to the environment. This means that the size of the radiator is the main factor affecting system thermal performance. Figure 11 shows the effect of vehicle speed on the refrigerant flow. It is seen that if the vehicle speed increases, the required power from the fuel cell stack increases and the refrigerant flow rate must be increased to match the increased waste heat output.

Fossil fuels used in vehicles cause environmental pollution in many ways. At the same time, the fossil fuel reserves are 
running out [19]. In some studies, alcohol based bio fuels are used as alternative fuels reducing the environmental pollution to some, but not sufficient extent [20, 21]. Since fuel cell vehicles use hydrogen as fuel, they emit only water vapors to the environment and cause zero environmental pollution. For this reason and because of the abundance of hydrogen in nature, they are seen as the technology of the future. Some researchers have simulated only one fuel cell power system, $[10,22]$ while others have examined the power requirements of the auxiliary equipment (pump, compressor, fan, etc.) required to operate, fuel and power management, and a power generating engine of the fuel cell $[10,12,14]$. However, a fuel cell engine system for a passenger vehicle has not been studied within a driving cycle. In this paper, a detailed study was conducted by examining and simulating the fuel cell system and thermal efficiency, the power requirements of the auxiliary equipment, the engine cooling system, and the radiator area required for this system. Real vehicle features were used. For this reason, this study eliminates the large experimental costs of the companies developing fuel cell vehicles and makes the development studies safer. From these perspectives, this paper paves the way on future studies that can be conducted in different real vehicles with different driving cycles.

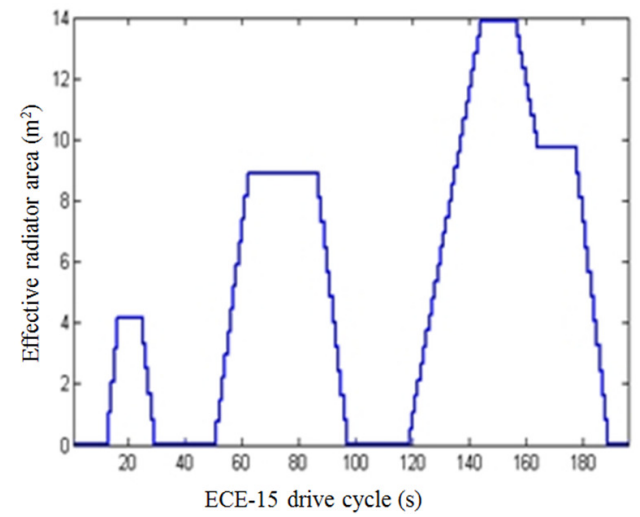

Fig. 10. Required radiator area according to speed values during the ECE15 drive cycle

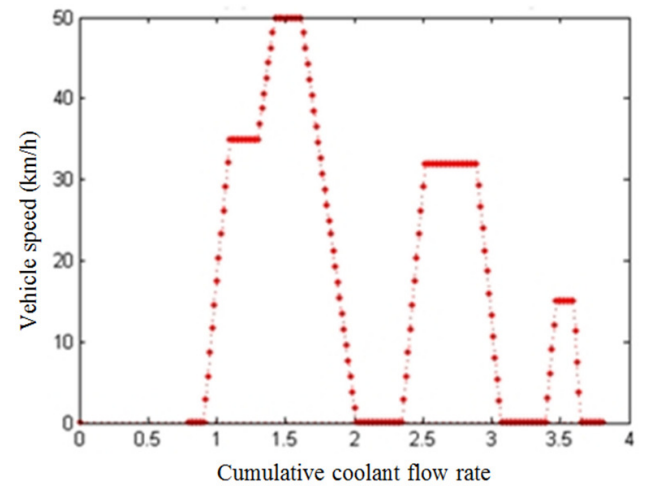

Fig. 11. Cumulative coolant flow ratio during the ECE-15 drive cycle

\section{CONCLUSIONS}

This paper has attempted to integrate component models for an automotive PEMFC system that includes fuel cell stack, air supply system, hydrogen supply system, and thermal circuit. Increase of the operating pressure of the system increases the fuel cell thermal efficiency but has no effect on the system thermal efficiency. The system pressure has a significant positive impact on the power density and water balance characteristics of the fuel cell. Increase of the vehicle speed has a negative impact on the system efficiency and stack efficiency. Auxiliary components are necessary to operate the PEMFC system but decrease its efficiency. Water management is one of the problems in systems that operate at low pressure because they need a large amount of water for the humidification process and the sizes of the humidifier and the condenser increase. This parasitic power requirement increases due to the fan condenser. Several improvements can be made to the PEMFC system model. The existing model can investigate the effects of stack geometry and fuel cell material properties on the system's performance. An improved model can be used to simulate the vehicle performance in different realistic driving cycles.

\section{ACKNOWLEDGEMENT}

The authors will like to thank the TUBITAK (Scientific and Technological Research Council of Turkey) for supporting this research.

\section{REFERENCES}

[1] Y. Wang, K. S. Chen, J. Mishler, S. C. Cho, X. C. Adroher, “A review of polymer electrolyte membrane fuel cells: Technology, applications, and needs on fundamental research", Applied Energy, Vol. 88, No. 4, pp. 981-1007, 2011

[2] A. Akroot, Modelling of thermal and water management in automotive polymer electrolyte membrane fuel cell systems, Hacettepe University, 2014

[3] J. Chakravorty, J. Saraswat, V. Bhatia, "Modeling a distributed power flow controller with a PEM fuel cell for power quality improvement", Engineering, Technology \& Applied Science Research, Vol. 8, No. 1, pp. 2585-2589, 2018

[4] J. Chakravorty, J. Saraswat, "Improving power flow capacity of transmission lines using DPFC with a PEM fuel cell", Engineering, Technology \& Applied Science Research, Vol. 9, No. 6, pp. 4883-4885, 2019

[5] T. J. P. Freire, E. R. Gonzalez, "Effect of membrane characteristics and humidification conditions on the impedance response of polymer electrolyte fuel cells", Journal of Electrochemical, Vol. 503, No. 1-2, pp. 57-68, 2001

[6] M. Amirinejad, S. Rowshanzamir, M. H. Eikani, "Effects of operating parameters on performance of a proton exchange membrane fuel cell", Journal of Power Sources, Vol. 161, No. 2, pp. 872-875, 2006

[7] W. Yuan, Y. Tang, M. Pan, Z. Li, B. Tang, "Model prediction of effects of operating parameters on proton exchange membrane fuel cell performance", Renewable Energy, Vol. 35, No. 3, pp. 656-666, 2010

[8] G. H. Guvelioglu, H. G. Stenger, "Flow rate and humidification effects on a PEM fuel cell performance and operation", Journal of Power Sources, Vol. 163, No. 2, pp. 882-891, 2007

[9] W. M. Yan, F. Chen, H. Y. Wu, C. Y. Soong, H. S. Chu, "Analysis of thermal and water management with temperature-dependent diffusion effects in membrane of proton exchange membrane fuel cells", Journal of Power Sources, Vol. 129, No. 2, pp. 127-137, 2004

[10] S. O. Mert, I. Dincer, Z. Ozcelik, "Performance investigation of a transportation PEM fuel cell system", International Journal of Hydrogen Energy, Vol. 37, No. 1, pp. 622-633, 2012

[11] M. Hosseini, A. H. Shamekhi, A. Yazdani, "Modeling and simulation of a PEM fuel cell (PEMFC) used in vehicles", SAE Technical Paper, No. 2012-01-1233, 2012 
[12] R. M. Moore, K. H. Hauer, D. Friedman, J. Cunningham, P. Badrinarayanan, S. Ramaswamy, A. Eggert, "A dynamic simulation tool for hydrogen FC vehicles", Journal of Power Sources, Vol. 141, No. 2, pp. 272-285, 2005

[13] D. Crolla, D. E. Foster, T. Kobayashi, N. D. Vaughan, Encyclopedia of automotive engineering, John Wiley \& Sons, 2014

[14] E. Hosseinzadeh, M. Rokni, A. Rabbani, H. H. Mortensen, "Thermal and water management of low temperature proton exchange membrane fuel cell in fork-lift truck power system", Applied Energy, Vol. 104, pp. 434-444, 2013

[15] J. Larminie, A. Dicks, Fuel cell systems explained, $2^{\text {nd }}$ Edition, John Wiley \& Sons, 2003

[16] R. O. Hayre, S. W. Cha, W. Colella, F. B. Prinz, Fuel cell fundamentals, John Wiley \& Sons, 2006

[17] F. Barbir, PEM fuel cells: Theory and practice, Elsevier, 2005

[18] C. Spiegel, Designing \& building fuel cells, McGraw-Hill, 2007

[19] Y. Cay, I. Korkmaz, A. Cicek, F. Kara, "Prediction of engine performance and exhaust emissions for gasoline and methanol using artificial neural network”, Energy, Vol. 50, pp. 177-186, 2013

[20] M. B. Celik, B. Ozdalyan, F. Alkan, "The use of pure methanol as fuel at high compression ratio in a single cylinder gasoline engine", Fuel, Vol. 90, No. 4, pp. 1591-1598, 2011

[21] N. Yilmaz, F. M. Vigil, K. Benalil, S. M. Davis, A. Calva, "Effect of biodiesel-butanol fuel blends on emissions and performance characteristics of a diesel engine", Fuel, Vol. 135, pp. 46-50, 2014

[22] J. Wishart, Z. Dong, M. Secanell, "Optimization of a PEM fuel cell system based on empirical data and a generalized electrochemical semiempirical model", Journal of Power Sources, Vol. 161, No. 2, pp. $1041-$ 1055, 2006 